\title{
Research of College English Writing Teaching Mode Based on Inquiry-based Learning
}

\author{
Xiaoxia Chen \\ School of Translation Studies \\ Qufu Normal University \\ Rizhao, Shandong, China
}

\begin{abstract}
As a new pedagogical method, inquiry-based learning (IBL) has changed students' learning style and teachers' teaching ideas, which places the student, the subject, and their interaction at the center of the learning experience. It emphasizes the diversity and scientificalness of the way of learning and teaching. Since it aims at the students' cultivation of innovation ability, problem consciousness, cooperation consciousness, and responsibility for the development of the reality, inquiry-based learning is also suitable for the teaching of English and other humanities. English writing, as a significant output activity, comprehensively reflects English proficiency of EFL (English as a Foreign Language) learners. Inquiry-based Learning is of guiding significance for English writing teaching. The paper puts forward college English writing teaching mode as both intelligent and feasible solutions from the perspectives of inquiry-based learning, hoping to improve the efficiency of English writing teaching.
\end{abstract}

Keywords-inquiry-based learning; college English writing teaching; English writing; learning style

\section{INTRODUCTION}

Finding its antecedents in constructivist learning theories, such as the work of Piaget, Dewey, Vygotsky, and Freire among others, inquiry-based learning lays stress on students' exploration and process, emotion and experience, communication and cooperation in the process of learning. As an integrated practical activity curriculum, it has such characteristics as comprehensiveness and practicality. As an organizational form of teaching, it is diverse and participatory. As a kind of learning style, it has such features as research and experience. Inquiry-based learning is essentially a kind of deep learning, which has a thought inheritance of long standing in the history of human teaching. When the cultivation of innovative spirit and practical ability has become the soul of the whole education, inquiry-based learning has attracted much attention because of it's practical values in education.

Inquiry-based learning has been used as a teaching and learning tool for thousands of years, and it is applicable in other subject areas where people are developing critical thinking and investigation skills. The theoretical research and practice of inquiry-based learning in China has experienced a gradual progress of more than 30 years: from the investigation of teaching methods to the interpretation curriculum policy, then to the research of teaching concept. Inquiry-based learning has been vigorous in fundamental education of China. It is an extremely important way to develop the creativity and practical ability of the students. Similarly, as one of the important subjects of the higher educational reform in China, it is significant for the teaching practice in recent years. As a compulsory course for English majors, English writing aims at developing students' basic English writing skills, then improving their ability to communicate with English writing. A lot of problems have perplexed college English writing teaching for a long time in China. By cultivating students' innovative spirit and practical ability, inquiry-based learning emphasizes students' exploration, experience, communication and cooperation in the process of learning. Therefore, it's urgent for English teachers and majors to have a comprehensive grasp of the concept and features of inquirybased learning. The paper proposes that college English writing teaching mode can be constructed to optimize English writing teaching from the perspectives of inquiry-based learning.

\section{A GENERAL REVIEW OF INQUIRY-BASED LEARNING}

As a response to traditional forms of instruction where students were required to memorize information from instructional materials, inquiry-based learning is primarily a pedagogical method, developed during the discovery learning movement of the 1960s. It is an umbrella term whose meaning is derived from the demand of practicing inquiry in science education and the increasing proliferation of computersupported collaborative learning in the past few years ( Koschmann, Hall, \& Miyake, 2001; Strijbos, Kirschner, \& Martens, 2004). It includes a range of teaching approaches in which learning is stimulated by a question or an issue, learning is based on constructing new understanding, the teacher's role is one of a facilitator, and there is a change towards selfdirected learning. Coming from constructivist learning theories, such as the work of Piaget, Dewey, Vygotsky, and others, inquiry-based learning can be considered a constructivist philosophy. According to Eick \& Reed ( 2002) inquiry-based learning (IBL) is a project-oriented pedagogic strategy based on constructivist and socio-constructivist theories of learning. In the process of developing IBL theory, Levy (2009) suggested that IBL can be either 'information-oriented' in which students focus on existing disciplinary knowledge, or 'discovery-oriented', participating in building disciplinary knowledge. Furthermore, the use of IBL as a pedagogical 
approach gained popularity at the time of John Dewey (18591952). Dewey's experiential learning pedagogy (that is, learning by doing) inspires the learner to participate actively in personal or authentic experiences to make meaning from it. Following Dewey's work, inquiry-based learning was adopted by many school teachers in the 1970 s. In recent years the application of IBL has been strengthening day by day as a teaching approach in response to a move towards studentcentered learning as well a means to strengthen the links between teaching and research.

\section{A. Characteristics of Inquiry-based Learning}

The importance of inquiry-based learning has been widely recognized. In order to apply it in English teaching, characteristics of inquiry-based learning should be clarified. "Inquiry" is defined as "a seeking for truth, information, or knowledge-seeking information by questioning." Inquirers will identify and research issues and questions to develop their knowledge or solutions. It implies involvement that leads to understanding. Inquiry-based learning includes problem-based learning, and and asks questions that come from the higher levels of Bloom's Taxonomy, such as analysis, synthesis and evaluation, which can motivate students. It utilizes a wide variety of resources and promotes meaning products with the guide or facilitation of the teacher.

Inquiry-based learning involves developing questions, making observations, doing research to find out what information is already recorded, developing methods for experiments, developing instruments for data collection, collecting, analyzing, and interpreting data, outlining possible explanations and creating predictions for future study. By compiling a variety of approaches to inquiry, Bell, T.; Urhahne, D.; Schanze, S.; Ploetzner, R. (2010) determined a set of nine categories that captured the space of ideas about inquiry held by the previous investigators. The nine categories are labeled as "main inquiry processes", namely, orienting and asking questions, hypothesis generation, planning, investigation, analysis and interpretation, model, conclusion and evaluation, communication and prediction. Specific learning processes that students engage in during inquiry-based learning are generated in the following "Fig. 1".

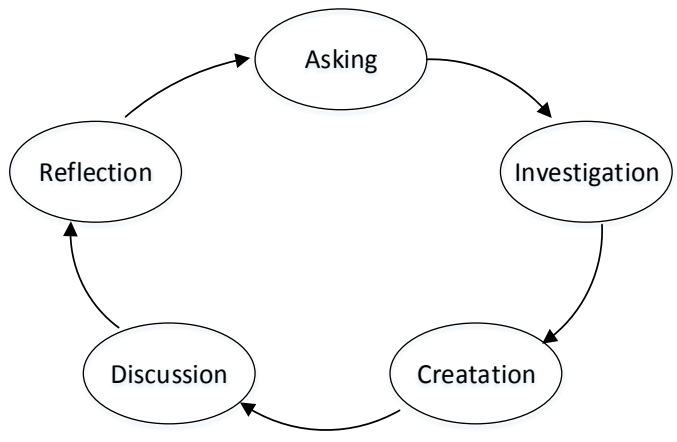

Fig. 1. Cyclic process of inquiry-based learning

They are sense-making processes and activities students are required to do. Inquiry-based learning starts by posing questions, problems or scenarios-rather than simply presenting established facts or portraying a smooth path to knowledge. The whole process is a cyclic process of learning.

\section{B. Differences between Inquiry-based Learning and the Traditional Approach}

Generally speaking, the traditional approach of teaching is focused on mastery of content, with less emphasis on the development of skills and the nurturing of inquiring attitudes. In the traditional system of education, the teacher focuses on giving out information about "what is known." Students are the receivers of information, and the teacher is the dispenser. Traditional education concerns more with preparation for the next grade level, neglecting to help students learn to learn throughout life. In traditional classrooms, it tends to be closed system where information is filtered through layers to students. Students become less prone to ask questions as they move through the grade levels, instead to listen and repeat the expected answers. Unfortunately, our traditional educational system has worked in a way that discourages the natural process of inquiry.

An old adage states: "Tell me and I forget, show me and I remember, involve me and I understand." The last part of this statement is the essence of inquiry-based learning. Inquirybased learning includes problem-based learning and involvement that leads to understanding. Involvement in problem-based learning implies possessing skills and attitudes that permit you to seek solutions to questions and issues while you construct new knowledge. The inquiry-based instruction places the student, the subject, and their interaction at the center of the learning experience. It is principally very closely related to the thinking and its development. Focusing on using and learning content as a means to develop informationprocessing and problem-solving skills, the inquiry approach is more student-centered, with the teacher as a facilitator of learning. There is more emphasis on "how we come to know" and less on "what we know." Students are more involved in the construction of knowledge through active involvement. Moreover, inquiry-based learning transforms the role of the teacher from that of dispensing knowledge to one of facilitating learning. It significantly increases the teacher's involvement in the thought-processes of the students.

In inquiry-based learning, classrooms tend to be open systems where students are encouraged to search and make use of resources beyond the classroom and the school, and teachers are facilitators of learning. The assessment of the learner is not focused on the importance of "one right answer", but on determining the progress of thinking and skills development. That is because inquiry-based learning is not only concerned with school success, but also preparation for life-long learning. The latter is the focus of the core of future world competition.

\section{CONNOTATION OF COLLEGE ENGLISH WRITING TEACHING BASED ON INQUIRY-BASED LEARNING}

Writing is a method of representing language in visual form. It's also a procedure of using symbols to communicate thoughts and ideas in a readable form. Among the four language skills - listening, speaking, reading and writing, writing is usually the difficult one to be acquired. English 
writing, as a significant output activity, comprehensively reflects English proficiency of EFL learners. Therefore, English writing teaching has been remaining an important part of college English teaching. Unfortunately, our traditional English writing teaching approaches are teacher-centered, and have worked in a way that discourages students' innovation ability, and problem consciousness. Inquiry-based learning is the inherent requirement of college English teaching. Therefore, it's urgent to introduce inquiry-based learning into college English writing teaching, and highlight it's great value and function for the cultivation of English majors, hoping to improve the teaching quality of college English writing teaching. Combining inquiry-based learning theory and teaching practice of college English teaching in China, inquirybased learning in college English writing teaching can be defined as inquiry learning and teaching process in which students, with the teacher's facilitation, actively learn and apply knowledge and skills required by college English writing, then develop innovation ability. The following four aspects will interpret the connotation of college English writing teaching based on inquiry-based learning.

\section{A. The Objective of College English Writing Teaching Based on Inquiry-based Learning}

As one of the important part of higher education in China, college English writing teaching should comply with and serve it's general objectives. The cultivation of innovative ability is a weak link in the college teaching. The conundrum which have been perplexing college English teaching is the cultivation of ability to analyze problem and propose ideas independently. Therefore, the direct objective of inquiry-based learning in college English writing teaching should be promoting students' logical thinking, critical thinking, innovation consciousness and ability to analyze and research. The improvement of these abilities will be reflected in the improvement of students' individual development and overall quality. Inquiry-based learning has changed students' learning style and teachers' teaching ideas, which encourages the students to experience the process, methods and norms of research, and to cultivate the spirit of science. That is the indirect objective inquiry-based learning in college English writing teaching.

\section{B. The Levels of College English Writing Teaching Based on Inquiry-based Learning}

Inquirers will identify and research issues and questions to develop people's knowledge or solutions. There are various levels of inquiry in inquiry-based learning. The article titled The Many Levels of Inquiry by Heather Banchi and Randy Bell (2008) clearly outlines four levels of inquiry, namely, confirmation inquiry, structured inquiry, guided inquiry and open/true inquiry. Banchi and Bell (2008) explain that teachers should begin their inquiry instruction at the lower levels and work their way to open inquiry in order to effectively develop students' inquiry skills. Open inquiry activities are only successful if students are motivated by intrinsic interests and if they are equipped with the skills to conduct their own research study.
College English writing teaching can draw lessons from the four levels of inquiry. In the first level-confirmation inquiry, the teacher has taught a particular writing theme or topic. Then, the teacher develops questions and a procedure that guides students through an activity. It is effective to reinforce concepts taught and to introduce students into learning, and to confirm and deepen understandings. In the second levelstructured inquiry, the teacher provides the initial question and an outline of the writing procedure, and students are to formulate outline of their findings through evaluating and analyzing the materials that they collect. In the third levelguided inquiry, the teacher provides only the topic question for the students. The students are responsible for designing and drafting their own writing, and then communicating their results and findings with the teacher and their peers. In the fourth level-open/true inquiry, the students finish their own writing, with the assessment of the teacher and their peers, and then formulate their own question(s) for the future writing and learning.

\section{The Principles of College English Writing Teaching Based on Inquiry-based Learning}

In order to ensure the effective implementation of inquirybased learning, the key principles should be concerned about. The teacher can use them to guide the creation of their inquirybased English writing teaching. The key principles of inquiry learning in college English writing teaching can be boiled down to three points below.

The first one is the principle of subjectivity. Inquiry-based learning places the student, the subject, and their interaction at the center of the learning experience. The systemic elements, such as the teacher, technology, instructional resources, and so forth, are prepared to support the learner. During the whole process of English writing teaching, from the selection and determination of writing topic, to the writing process, then to the summary of writing, teachers should create conditions and opportunities as much as possible to encourage students should learn independently.

The second one is the principle of symbiosis. Inquiry-based learning transforms the role of the teacher from that of dispensing knowledge to one of facilitating learning. It's selfevident that the inquiry-based learning process is studentcentered and students are active participants in the teaching process. At the same time, the teacher also becomes a learner by finding out more about the learner and the process of inquiry learning. The teaching process is the process of students' development, also that of the teacher's improvement. So, it is a process that teaching benefits teachers as well as students.

The third one is the principle of progressiveness. There are four levels of inquiry in college English writing teaching. They are progressive, from the lower to the higher levels. Therefore, inquiry-based learning in college English writing teaching must present progressiveness, that is, from simplicity to complexity, from low-level to high-level. Simplicity and lowlevel is to adapt to the students' initial level. Complexity and high-level is to move to the ultimate goal of inquiry-based learning. 


\section{THE CONSTRUCTION OF COLLEGE ENGLISH WRITING TEACHING MODE BASED ON INQUIRY-BASED LEARNING}

\section{A. The Current Problems of College English Writing Teaching in China}

As an important way of language output, English writing reflects students' English comprehensive ability so that it has attracted teachers' and students' more attention. Therefore, college English writing teaching has always been highly valued by the education circle in China. Unfortunately, the effect of college English writing teaching in China is still not satisfactory, due to the complexity of the teaching of foreign language writing. There are still a lot of problems to be solved in college English writing teaching in China.

1) The inexplicit phased objective of college English writing teaching: English majors have been learning English for years, but English writing is still their weak point which has plagued them for long time. Students started to learn English writing in middle school, aiming at coping with the problems of English writing in college entrance examination. When they came into college, English majors still learn English writing, but with the aim of preparation for the test for English majors-band $4 \& 8$. This kind of examinationoriented English writing teaching is not real writing teaching, for it has no explicit phased objective to develop students' English writing ability and comprehensive skills.

2) The unapparent compatibility of college English writing teaching: English writing, as an important output activity, reflects English proficiency of EFL learners comprehensively, for it is not only associated with vocabulary, grammar and sentences, but also English thinking pattern, etc. The improvement of English writing ability must be based on the basic skills of vocabulary and grammar, etc. And likewise, the improvement of English writing ability can also promote that of listening, speaking and reading ability. Unfortunately, the curriculum design for English Majors is too divided, minimizing the cultivation of language basic skill. The compatibility of college English writing teaching with other basic courses is unapparent.

3) The obsolete teaching method of college English writing teaching: For a long time, the product-oriented model is the traditional model of English writing teaching in China, which puts the students under the control of the teacher. There is no freedom for the students to create, making writing become a boring and mechanical process. The teachers are tired of correcting composition, and the students are reluctant to revise and rewrite the composition, resulting in unsatisfactory teaching effect of college English writing teaching.

\section{B. The Construction of College English Writing Teaching Mode Based on Inquiry-based Learning}

According to the characteristics of inquiry-based learning and college English writing teaching in China, a tentative construction of college English writing teaching mode on the basis of inquiry-based learning is made. It is a dynamic and compatible mode, which can promote the students' creative ability, problem-solving ability, and promote the students' autonomous learning and cooperative learning enthusiasm. The college English writing teaching mode based on inquirybased learning is shown below in "Fig. 2".

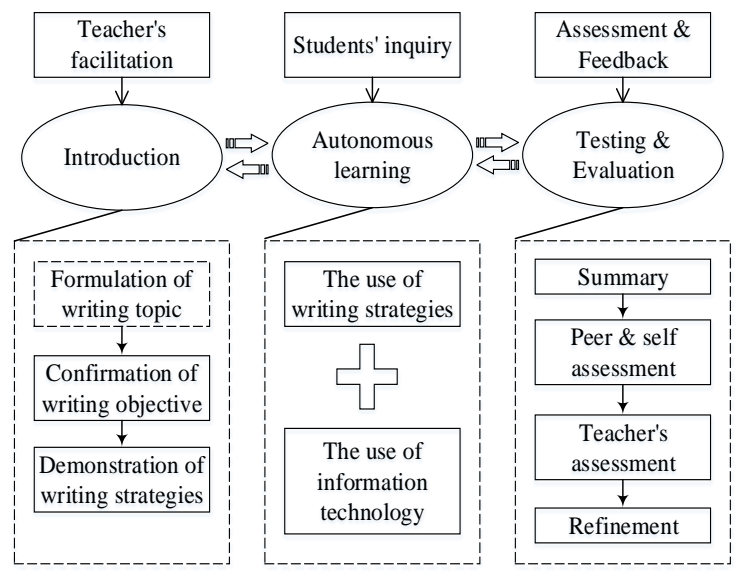

Fig. 2. The college English writing teaching mode based on inquiry-based learning

1) The teacher's scientific facilitation: The teacher's role in inquiry-based learning is quite different. The teacher sees him or herself as a mediator of students' learning, but not controller. The teacher gives students projects to work on, problems to solve and strategies to use. And then the teacher intervenes between the student and the project or the problem by asking such questions as: How are you going to approach this problem? What are the resources that you're going to need? How would you know when you're successful? So, the teacher is a problem presenter, at least initially.

An appropriate facilitation plan allows the teacher to plan ahead and prepare for many challenges and pitfalls that might turn up along the learning path. It provides direction but does not specify one path and thus promote students' creativity and responsibility. Therefore, the teacher's scientific facilitation will ensure a good beginning of college English writing teaching.

2) The students' initiative participation: The core of implementation of inquiry-based learning in college English writing teaching is the students' initiative participation, which can determine the degree and effect of implementation of inquiry-based learning. The students' initiative participation and the cultivation of their inquiry spirit run throughout the whole process of college English writing teaching. They should learn and inquiry not only the writing topic and writing strategies, but the information technology which is aimed at answering questions and providing up-to-date information. In the final procure of English writing teaching, students initiative participation in peer assessment and self-assessment will benefit them more.

3) The comprehensive assessment strategies: The focus of assessment of inquiry learning should be on the following: the degree to which the processing of learning skills has been 
developed, the degree to which the habits of mind, or have been nurtured and the degree to which students have developed the content knowledge, set in a context of broad understanding. Therefore, the old-fashioned product-based assessment techniques can't satisfy. In college English writing teaching, the comprehensive assessment strategies are also needed urgently. They consist of not only traditional testing but also some up-to-date assessment strategies. After a long period of inquiry-based learning, students will become continuous learners rather than just be the subject of someone' evaluation and assessment.

\section{A Sample Model of a Typical Class in an Ibl College English Writing Course}

In IBL college English writing teaching, there are lots of challenges the teacher might face, which are systemic in nature. If such elements as the administrative support, the design of facilities, the instructional resources, and etc. are not aligned and supportive of inquiry learning, then the teacher may have difficulty implementing inquiry-based learning in the classroom. Another challenge to inquiry-based learning is the non-supportive attitudes of some parents, community leaders, and educators. However, it is an austere challenge for the teachers, but also a rare opportunity. To meet these challenges and to use inquiry-based learning, teachers must first educate themselves about the process and then help convince others of its value.

Due to the variance across the environments and needs at institutions across the nation and world, a typical class in an IBL college English writing course is hard to define. But it is a specific exhibition inquiry-based learning in college English writing teaching. In order to show it specifically, a sample model of inquiry-based learning in college English writing course is designed below in "Fig. 3".

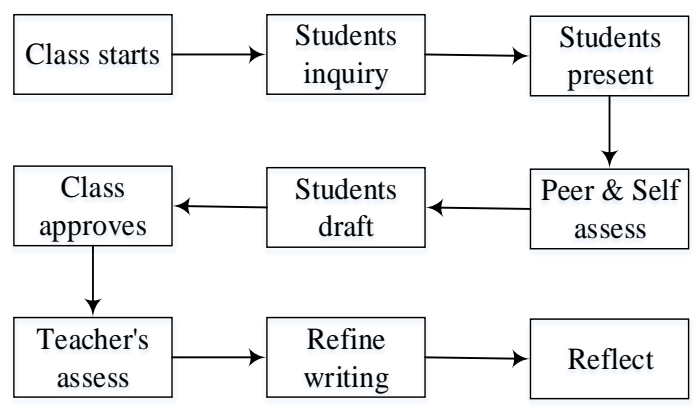

Fig. 3. A sample model of an IBL college English writing course

It shows the teaching procedure of an IBL college English writing course. When the class starts, the teacher introduces the writing topic and ask some questions about this topic. Then the students inquiry the related aspects of writing topic by using all kinds of technology. After inquiry and discussion, the students who have prepared well present their results one by one. The teacher and the students approve the perspective, strategies and outline of writing. Then, students begin to draft their composition. The next two steps are the comprehensive assessment, coming from peers and themselves and the teacher. In the last two steps, question are asked to help students refine their writing, teachers and students reflect their teaching and learning.

\section{CONCLUSION}

This research presents a brief introduction of inquiry-based learning, and briefly analyzes the particularity and the existing problems in college English writing teaching in China. Combining inquiry-based learning and college English writing teaching, a tentative college English writing teaching mode is put forward to improve the efficiency of English writing teaching. The mode clarifies the relationship between the various factors in college English writing teaching in China, promoting the compatibility of college English writing course and other courses. There is no doubt that the mode also should be continuously improved in the teaching practice. That is the focus of the future research.

\section{REFERENCES}

[1] Banchi H, Bell R. The Many Levels of Inquiry.[J]. Science \& Children, 2008, 46:26-29.

[2] Chu K W S. Inquiry project - based learning with a partnership of three types of teachers and the school librarian[J]. Journal of the American Society for Information Science \& Technology, 2009, 60 (8): 16711686.

[3] Deanna Kuhn, Maria Pease. What Needs to Develop in the Development of Inquiry Skills?.[J]. Cognition \& Instruction, 2008, 26 (4): $512-559$

[4] Dewey, J. How We Think [M]. New York: Dover Publications, 1997.

[5] Edelson D C, Pea R D. Addressing the Challenges of Inquiry-based Learning through Technology and Curriculum Design[J]. Journal of the Learning Sciences, 1999, 8 (3): 391-450.

[6] Eick C J, Reed C J. What makes an inquiry-oriented science teacher? The influence of learning histories on student teacher role identity and practice[J]. Science Education, 2002, 86 (3): 401-416.

[7] Freire, P. Pedagogy of the Oppressed [M]. New York: Continuum Publishing Company, 1984.

[8] Koschmann, T., Hall, R., \& Miyake, N. (Eds.). CSCL 2 carrying forward the conversation. Mahwah[M]. NJ: Lawrence Erlbaum, 2001

[9] Levy, P. Inquiry-based learning: A conceptual framework. Centre for Inquiry-based Learning in the Arts and Social Sciences [M]. Sheffield: University of Sheffield, 2009

[10] LI, C. Research on the English Writing Teaching Mode "Inquiry Cooperative Learning" [J]. Journal of Wen Shan University, 2011, 24 (6): 99-102.

[11] LIU, N M. Construction of the System of Project-based Inquiry Learning for English Majors[J]. Journal of Huaihai Institute of Technology, 2010, 08 (12): 79-82.

[12] Spronken-Smith R A, Walker R, Dickinson K J M, et al. Redesigning a curriculum for inquiry: an ecology case study[J]. Instructional Science, 2011, 39 (5): 721-735.

[13] Strijbos, J. W., Kirschner, P. A., \& Martens, R. L. (Eds.). What we know about CSCL andimplementing it in higher education[M]. Boston, MA: Kluwer Academic Punlishers, 2004.

[14] Thorsten Bell, Detlef Urhahne, Sascha Schanze, et al. Collaborative Inquiry Learning: Models, tools, and challenges[J]. International Journal of Science Education, 2010, 32 (3): 349-377.

[15] Vygotsky, L.S. Thought and Language[M]. Cambridge, MA: MIT Press, 1962. 